\title{
7. Critical Practices and Assemblages of Solidarity
}

The final chapter seeks to discuss practices and assemblages of solidarity from a critical race and decolonial perspective. Based on discussions about solidarity with Mapuche and non-Mapuche interlocutors and from my activist ethnography, I will elaborate on a critical notion of solidarity across and beyond differences.

This critical notion of solidarity will be developed in three steps, each introducing a critical principle of solidarity. The first principle will discuss solidarity as compromiso-a long-term engagement and commitment that overcomes paternalistic practices and decentres white agency. Instead, solidarity as compromiso requires a radical form of passivity by white supporters and critical practices that can be expressed in a series of metaphors.

The second principle describes critical practices of sharing-compartir-as a form of solidarity. Compartir can include the exchange of material and immaterial goods, the sharing of spaces and gifts, as well as forms of spending/sharing time together. Different forms and modalities of compartir will be critically discussed by asking whether they contribute to an exploitative or rather a reciprocal relationship between Mapuche and non-Mapuche actors.

The third principle introduces solidarity as a critical practice that (re)produces communal and social bonds between the involved actors, which is expressed in the Mapuche ideas of keyuwvn and mingako. Critical practices and encounters of solidarity between Mapuche and non-Mapuche are called to be mutually transformative, reciprocal, and horizontal, taking place on a longterm and intimate basis. These factors thus transform the political encounters and relations of solidarity into social bonds between the involved actors. In these assemblages, the productive and transformative potential of a critical notion of solidarity becomes visible. The idea of assemblages of solidarity then "allow[s] us to ask about communal effects [of international solidarity] 
without assuming them" (Tsing 2015, 23). In other words, this critical idea of solidarity is without guarantees. Such communal effects, in the present case, will be discussed as processes of identification, recognition, belonging, mimesis, and, finally, as relations of kinship and friendship.

An ethnographic experience invited me to consider these three critical principles and their entanglement. Whilst preparing for my first fieldtrip to Wallmapu in early 2016, I conducted several interviews with non-Mapuche solidarity activists. After having interviewed Clarissa, a white German woman, she offered to put me in contact with a Chilean family in Temuco, where she had stayed during her university exchange in Chile. I gladly accepted and soon arranged my accommodation with them.

However, after a few days in their house, I decided that I had to leave as soon as possible. I was shocked that even in a few moments of interaction they had made so many derogatory and racist remarks about the Mapuche that I was not able to stay with them any longer. Fortunately, I already encountered several welcoming and friendly people amongst the Mapuche movement in town who helped me to find a new accommodation within a few hours. They introduced me to Rayen Kvyeh, who at that moment was subletting a room in her house, where I would stay for the following weeks.

Besides my frustration about the racism of white Chileans, I could not stop wondering about the meaning of this experience. Why did Clarissa, considering herself in solidarity with the Mapuche, stay with that family and even recommended them to me? She must have heard many more similar comments during her considerably longer sojourn with them. I shared this story with some of my Mapuche interlocutors in Temuco and Vicente Painel finally gave me a clue. He said that for Clarissa it was not a contradiction to stay with a racist family and consider herself in solidarity with the Mapuche. In contrast, being in solidarity means to transform oneself, to give up one's own comfort zone and, for example, even to look for a new place to stay, eat, and live together with different people. For Vicente Painel, her commitment (or lack of commitment) with the Mapuche was reflected by her actions and practical decisions. A decolonial perspective on solidarity, however, demands a transformation of one's commitment into critical practice and social relationships.

This chapter is a continuation of this reflection. My decision to leave the safe space of my accommodation created possibilities for encounters with Mapuche people that eventually became much more than just political relations of solidarity. My and Clarissa's experiences reflect how transnational 
advocacy and international solidarity with the Mapuche provide spaces of (dis)encounter between Mapuche and non-Mapuche actors in a conflictive postcolonial contact zone (Pratt 1992, 4-7). In these encounters, the political practice in solidarity has the potential to produce and transform the relationships between the involved actors connected across unequal power relations and geographies (Featherstone 2012). The present chapter will show what kind of political practices of solidarity take place within the rhizomatic solidarity network and how they transform, constitute, and assemble social relations of solidarity between Mapuche and non-Mapuche.

\section{Solidarity as Compromiso: Towards a Critical Praxis of Solidarity}

The transformation of such relations depends on how solidarity is carried out, practiced, performed, and enacted-in short, on the praxis of solidarity. ${ }^{1} \mathrm{Be}$ sides the efforts in transnational advocacy and different solidarity projects, to look at the praxis of political solidarity means to understand how it is embedded and expressed as a social praxis within a racialised and postcolonial "space in which peoples geographically and historically separated come into contact with each other" (Mahrouse 2014, 16). This praxis exists in "in terms of co-presence, interaction, interlocking understandings and practices" and informs "how subjects are constituted in and by their relations to each other" (Pratt quoted in Mahrouse 2014, 16).

The specific praxis of solidarity can be "grounded in presence and participations [...] that bring people together" (Squire 2018, 124-25) and in particular moments of encounters, mobilisations, or protests "because they enact solidarities in a dynamic form" (Ibid., 295; my emphasis). A practical (but also a decolonising) notion of political solidarity thus must start from a concrete praxis by the involved actors, since the "only way to build a radical alternative present is to make it on the ground, in real time, with real people" (Simpson, Walcott, and Coulthard 2018, 81). In other words, the performative potential of solidarity depends on its praxis (Ahmed 2004). So, what is actually being

The notion of praxis is inspired by the work of Pierre Bourdieu (1990), who argues for looking particularly at social practices to understand our societies. With the notion of praxis, Bourdieu manages to understand especially those practices whose immediate meaning and significance is hidden to the involved actors. To understand solidarity as a social praxis thus further accentuates its transformative potential. 
done in political practices within transnational advocacy and international solidarity? How do non-Mapuche activists act?

To begin with, several statements describe the involvement of nonMapuche solidarity actors as help and support, for example, in the context of preparing solidarity events, translating, doing legal research, joining the visits by Mapuche delegations to Europe, or being present at demonstrations.

They often characterised their help and support in a manner that understates their agency. For example, they did "a lot of small things" (Amina, interview with the author, November 27, 2015) and were a "helping hand" (Amanda, interview with the author, July 1, 2016). For Amanda, helping is "[lending] myself, uhm, to anything productive that I can do, anything that I could do to forward the cause." (Amanda, interview with the author, July 5, 2016) In concrete terms, her support of the Mapuche foundation FOLIL includes, for example, writing a statement on short notice, doing a translation, publicising an event, etc. Essentially, non-Mapuche solidarity actors understand their help and support as putting themselves at the service of the already ongoing efforts of the Mapuche diaspora in a spontaneous, practical, and productive manner.

Such statements are reflective about possible power imbalances, downplay white agency and, in contrast, support the autonomous efforts of the Mapuche. Nevertheless, help and support are not uncontested notions when it comes to describing solidarity action. They are also the subject of some critiques, since they are connected to an individualised practice and a paternalistic concern about something or someone. Such notions further reproduce subjectivities of the white saviour and might contribute to avoiding a thorough political analysis. Finally, the site of intervention remains solely within the lifeworlds of Indigenous people and rarely seeks to identify common aspects of a political struggle shared by Indigenous and non-Indigenous people alike (Land 2015, 205-8).

Another common practice of political solidarity in the present case are visits from Europe to Wallmapu. Such visits are portrayed as face-to-face encounters over a small period of time in Mapuche communities or with political prisoners in jail by solidarity actors. Experiences of such visits were narrated in mostly enthusiastic terms, because they made the host feel important, interesting, or appeased (Cristián, interview with the author, March 8, 2016; José Luis Calfucura, interview with the author, February 16, 2016a; Radio Mapuche 2015). At the same time, most of the non-Mapuche actors were excited about the possibility or experience of visiting a Mapuche community in Wallmapu. 
Visits by non-Mapuche actors or representatives of non-Indigenous organisations give transparency and legitimacy to their solidarity projects as well as to the particular political projects of those being visited. This is because the visits of international delegations were depicted as expressions of political commonalities (Isabel Cañet, interview with the author, February 24, 2016; Jaime Huenchullán, interview with the author, March 20, 2016; Rayen Kvyeh, interview with the author, March 1, 2016). Visitors were referred to in a way that implied that the practice of visiting produces political allyship.

Such visits are embedded in the strategic and generalised disposition of the Mapuche to have political dialogues with non-Mapuche representatives. The important aspect is that these visits are necessary to discuss ideas and projects of solidarity as a condition of a possible future collaboration. Visitors who come on the recommendation of someone the community already knows are especially welcome: "when he or she comes in that way, we are always willing to receive him or her" (Jaime Huenchullán, interview with the author, March 20, 2016).

If these visits are a condition for initiating a project with the community, it means that there can hardly be any solidarity with a Mapuche community or organisation without visiting them. Finally, such visits constitute possible transformative encounters of solidarity in which white privilege can be enforced or destabilised (Mahrouse 2014, 146). For a non-Indigenous person, visiting an unfamiliar territory and being in a minority position can have positive transformative potential since "the process of being uncomfortable is essential for non-Indigenous people to move from being enemy to adversary to ally" (Regan quoted in Land 2015, 218). In my personal experiences and visits to Mapuche communities and political prisoners, I felt that these encounters also provide spaces to challenge Maputhusiasm and the idea of the hyperreal Mapuche. In that way, solidarity is transformative because it produces encounters with actual people with whom you have a sit-down, share a meal, a mate, tears, or a good laugh.

Another way of practicing solidarity in face-to-face encounters is the idea of insertion. In my visit to the Jesuit Mapuche Mission (JMM) in Tirúa, Juan Fuenzálida expressed the following idea in our dialogue: insertion would not mean only a short visit, but a constant and close side-by-side between Mapuche and non-Mapuche people in a certain territory. He describes their work as a "dynamic of insertion," "where the 'how' is much more important than the "what". Insertion, according to him, "has to do with the way of presence" 
and "becoming neighbours"- not as an institution but as an "inserted, more simple presence" (interview with the author, March 12, 2016).

Practices of solidarity thus arise from within this insertion. This could mean helping to fix the water supply, helping out in the households, escorting someone to do bureaucratic formalities, or taking someone to the doctor. Insertion is about "trying to accompany life and accompany the processes that are, on the one hand, more communal, and, on the other, also often very domestic and personal." ${ }^{2}$ An insertion does not only mean sharing time and resources on a local and long-term level, but also becoming an agent of a political process and sharing the conviction for struggling for the same cause.

Another important way of describing one's practical commitment is the Spanish term compromiso, which does not have a proper translation into English. ${ }^{3}$ An illuminating description for compromiso is

the action or attitude of the intellectual, who by becoming conscious about her/his belonging to society and the world at the moment, renounces her/his position as a mere observer and puts his thinking or art at the service of a cause. [...] The compromiso with that cause of a fundamental transformation [of society] is the valid action. (Fals-Borda 2009, 243; my translation)

Here, the inner attitude of the compromiso is transformed into a political practice that demands renouncing one's privileges and making them useful for a particular political cause. The compromiso can be further understood as a self-binding commitment and voluntary act on behalf of the consciousness, located within one's own positionality, that contributes to maintaining and preserving life (Garbe, Cárdenas, and Sempértegui 2018, 13, 139).

A critical discussion of solidarity thus needs to consider how interpersonal practices in solidarity and advocacy activism reaffirm white agency and protagonism. At the same time, it requires finding those practices of solidarity that do not reproduce colonial and racialised hierarchies.

2 He further relates this way of practicing solidarity as part of his perspective from Latin American liberation theology. Nevertheless, the idea of insertion also appears within the proposals for participatory action research developed by Orlando Fals-Borda. In his radically committed research methodology, insertion involves "get[ting] involved as an agent within the process one is studying, because one has taken a stand in favour of certain alternatives [...]" (Fals-Borda 2009, 235; my translation).

3 I believe that notions like commitment, engagement, involvement, or responsibility do not completely grasp its meanings. 
The heterogenous ways of how non-Mapuche people act or behave within the context of advocacy and solidarity express different modalities of solidarity. From a critical race and decolonial perspective, these modalities are particularly interesting because they point towards the ways in which agency between different actors is distributed. A critique of white and non-Mapuche agency in solidarity critically analyses those experiences in which the protagonism of non-Mapuche actors compromises the cultural politics of autonomy of the Mapuche involved.

It is important to start with a critique of solidarity projects that are initiated by non-Mapuche actors, which include most of the projects of my non-Mapuche interview partners, including my own research. A movie documentary and a photography project to raise international awareness about the situation in Wallmapu were initiated by white Europeans, other nonMapuche activists offered their support to diasporic Mapuche organisations, and the drive of Adveniat to financially support the three local projects in Tirúa, Temuco, and Santiago de Chile came from Germany. As the initiation of a project by non-Mapuche actors is an expression of white agency, I now want to discuss if and how white agency is played out and negotiated within particular experiences of solidarity.

During my research stay in Temuco, I met one non-Mapuche activist, Alma, with a strong "impulse towards action" (Ahmed 2004, para. 56). I spent a considerable amount of time with Alma (conversations with the author, February-April, 2016) and, whilst her presence and actions were largely welcomed by Mapuche hosts, she put herself into several dangerous situations. For example, after a Mapuche community centre in Temuco was violently raided by the military police, she decided to spend the night there in order to accompany those who remained, even though people close to her wanted to hold her back because the situation was still unsafe. Also, in her visits to the political prisoners in Temuco, she did not comply with some basic safety measures that we were instructed to follow. ${ }^{4}$ I had the impression-and some of my Mapuche interlocutors agreed-that she was overcompensating by trying to help as much as possible. I discussed her behaviour with our hosts, who were worried about her physical as well as psychological—in their words, spiritual-wellbeing. For instance, she could have been locked up, beaten by the 
police, or worse. However, our warnings were ignored. Such an impulse for action or actionism can have different reasons, which may be contradictory:

The impulse towards action is understandable and complicated; it can be both a defense against the 'shock' of hearing about racism [...]; it can be an impulse to reconciliation as a 're-covering' of the past (the desire to feel better); it can be about making public one's judgment ('what happened was wrong'); or it can be an expression of solidarity ('I am with you'); or it can simply be an orientation towards the openness of the future (rephrased as: 'what can be done?'). (Ahmed 2004, para. 56)

What was problematic in the case of Alma was that her impulse to action required the care and attention of our Mapuche hosts that could have been directed towards their community and family members instead. This is an ambiguous outcome in situations of racial stress or violence, in which white people demand excessively more emotional care than those who suffer from it - a phenomenon coined with the term "white fragility" (DiAngelo 2011). After discussing her behaviour, we agreed on confronting her carefully, but did not succeed in getting through. It is an unfortunate confirmation of the claim that the impulse to action ultimately "can work to block hearing" (Ahmed 2004, para. 56). Such paternalistic practices of solidarity reproduce unequal and hierarchical relations between white people and People of Colour and have harmful effects for the latter (Ahmed 2004).

I experienced several situations of such paternalistic expressions of solidarity. For example, in the event in Bad Ems, Barbara Katz was described as the "defender of the Mapuche people." This phrasing reproduces a colonial stereotype about Indigenous people who are not able to help themselves and thus need protection by white people. It recentres the agency on one white woman, who is heroised, whilst at the same time collectivising and deindividualising the Mapuche people, as she becomes the defender of a whole society.

In another example, Eva was not shy in hiding her agency in the planning and organisation of her microfinance project. ${ }^{5}$ Her statements reproduce a Western subject who considers him/herself cognisant about the problems of

5 She revealed that she reflected (by herself) about "what could be the best option" for a development project within a Mapuche community and finally "came up with this project". Put differently, she "looked at the problems, thought about what could be done and [...] found the solution [...]" (Eva, interview with the author, December 1 , 2015a) 
the Mapuche and offers a solution. The fact that there might be other valid or very different reflections or proposals about problems of the Mapuche society is ignored.

Such a paternalism was rejected by some Mapuche interview partners, because it means that non-Mapuche actors assume too much protagonism within solidarity work. Paternalistic practices are dialectical in a way that the agency of one group (non-Mapuche) has an immediate effect on the possibilities of action by another one (the Mapuche). In other words, paternalism describes the practical and performative (re)production of the subaltern as the one who cannot speak but needs someone to speak for him or her (Spivak 1988).

Whilst the impulse towards action blocks listening, paternalism contributes to silencing the Mapuche by pretending to support them. The paternalism of non-Mapuche Chileans has been especially criticised because "they want to talk for you, but don't want you to talk" (Llanquiray Painemal, interview with the author, June 16, 2017). Whenever I experienced or heard about such an attitude by other non-Mapuche actors, they were harshly sanctioned and rejected by the Mapuche.

In contrast to the impulse towards action and paternalism, two alternative practices of solidarity minimise white agency and show consideration of the autonomy of the Mapuche.

First, on several occasions Mapuche interlocutors demanded a certain degree of cautiousness by non-Mapuche activists. For example, whilst preparing my trip to Wallmapu, activists from the Mapuche diaspora urged me to be careful when doing fieldwork and human rights observations. These statements pointed out the potential risk of my behaviour and praxis for the communities I would visit, as well as for myself, for instance in becoming the target of repression. Particularly, they requested not to behave inappropriately or disrespectfully, since I would be visiting some communities based on their recommendation.

Some non-Mapuche activists did show some awareness about the need to act carefully. For example, I asked Amina what she would do differently in another trip to Wallmapu. She emphasises that she would be "much, much more careful" (interview with the author, November 27, 2015), because her first visit led to internal friction inside a community. Amanda too claims that her experience of supporting a diasporic Mapuche organisation has made her "really careful about speaking on anyone's behalf, so in that sense I really am 
wary of it [...]" (interview with the author, July 1, 2016). Rike describes her engagement as "in no way influencing or prescribing what is good or bad" but as a "position in the background" (interview with the author, May 27, 2016).

Another idea of practicing solidarity without reinforcing white agency was articulated as passivity or the complete lack of agency. For example, Amina does not see herself as "the person, who would go around in Chile somehow looking for collaboration" (interview with the author, November 27, 2015). Instead, she notes that this should be the task of diasporic Mapuche. She explains that she would only consider continuing collaborating if she is approached by Mapuche and asked for support but would not push forward a project by herself since she is "not sure if that is actually wanted" (Ibid.).

Activists from the Mapuche diaspora articulated a similar idea by acknowledging that they, for example, do not have "the moral position" and "do not have the right to politically define" what would benefit a Mapuche community (Alex Mora, interview with the author, November 28, 2015). This more passive approach seeks to show consideration towards the autonomy of Mapuche community and organisations in Wallmapu. This is because, as Juan Fuenzálida explains, "there is also a political Mapuche life in autonomy which demands a certain distance from us" (interview with the author, March 12, 2016). Thus, their autonomy is respected by remaining in a more passive and distant position, which needs to be regulated actively.

This actively regulated passivity resonates with the notion of a (radical) passivity ${ }^{6}$ as a form of political solidarity praxis. This kind of passivity is produced in encounters of solidarity in which non-Mapuche actors are challenged to actively give up a great part of their protagonism. As a decolonial approach to solidarity, the idea of a radical passivity seems illuminating for navigating the power imbalances within political solidarity practices, decentring white agency, and being attentive to the autonomy of the Mapuche. But this idea also highlights the fact that the passivity of powerful actors can only be exerted due to existing privileges and does not remove them completely. This means that a radical passivity remains critical and precarious because,

6 A radical kind of passivity does not only mean to remain passive but to actively move towards passivity and become "passive with regard to itself" (Wall 1999, 1; emphasis in original). It is the action of stepping out of the spotlight and not waiting until the spotlight moves on. This passivity is a radical one to the "extent that [it] articulates an extreme passivity, expropriation, de-nucleation, or neutrality that is paradoxically constitutive of the self, the image, or the community" (Wall 1999, 7; emphasis in original). 
as a result of existing privileges, it can be withdrawn and white agency reinstalled. The notion thus remains problematic, since white actors keep a privilege through which they can choose passivity over agency.

Another approach to uncovering critical notions of solidarity practices comprises looking at the metaphors that the involved actors use. Whilst the critique of some solidarity practices is important, this research is also interested in understanding decolonial possibilities for more horizontal practices of solidarity across power imbalance. Such possibilities were expressed in a series of metaphors by non-Mapuche and Mapuche actors.

Several non-Mapuche activists described their contributions as small and modest. These statements express an awareness about their support not "turn[ing] everything upside down" (Amina, interview with the author, November 27,2015 ) and that they are not able to "change the world" (Isabell, interview with the author, June 9, 2016; Verena, interview with the author, December 6, 2015). This awareness is critical to white agency and its impulse towards action, whilst leaving non-Mapuche activists with a positive feeling of being able to contribute: "I really feel amazed that I can play even the smallest part [...]" (Amanda, interview with the author, July 5, 2016).

Such practices were described metaphorically as "building blocks" that contribute to transnational advocacy and international solidarity. On the one side, these blocks finally would add up to a path towards more substantial change, which should be built "in consultation or commissioned by the affected group" (Isabell, interview with the author, June 9, 2016). On the other hand, these blocks were depicted as parts of a "mosaic in what could maybe be done and achieved" (Sybille, interview with the author, June 26, 2016).

An interpretation of solidarity as 'building blocks' points in two different directions of how to understand contemporary expressions of political action. On the one hand, limiting solidarity to small contributions can be a symptom of the melancholia over the possibility for systemic or even revolutionary change based on the experience of failed political projects of the Left throughout the twentieth century (Traverso 2017). On the other, the contemporary heterogeneity of political projects of the Left is also analysed as a mosaic, in which "the Left can be understood as an association of field actors, who contribute to a progressive transformation within their fields, in order to enable agency [...] beyond their field" (Urban 2007; my translation). I contend that the metaphor presented above and its underlying understanding of soli- 
darity as a critical praxis is caught in the contradiction between two analyses, wherein each manages to highlight a particular dimension.

Another way interviewees describe the praxis of solidarity is through the metaphor of healing. In situations of personal or collective suffering and traumas, healing aims to "generate positive [human] beings" as a reaction to when "there is only pain" (Alex Mora, interview with the author, November 28, 2015). Practices and encounters of solidarity thus would provide opportunities for the involved people to get to know each other better and, consequently, to heal each other (José Luis Calfucura, interview with the author, February 16, 2016b)

Rayen Kvyeh describes her exile in Germany in the 1980 s as an experience of healing, which was supported by her (German) comrades and a "feeling of strong friendship" (Rayen Kvyeh, interview with the author, March 1, 2016). Solidarity thus is presented as a praxis that aims to "heal souls [and] heal people" (Pastoral Mapuche, group discussion, April 6, 2016). It is, according to this metaphor, about contributing to and caring about the emotional, affective, psychological, and physical well-being of all the people involved.

Almost all the political events in the context of transnational advocacy and international solidarity that I experienced included a sort of shared meal. This is true for both the contexts of Europe and Wallmapu. Political meetings, actions, demonstrations, or simple visits always included eating together-at the very least a snack and tea. Based on that experience, eating together can count as a metaphor for a critical praxis of solidarity.

It is particularly interesting how people give meaning to these shared moments. In my experience, eating became an essential part of working collaboratively. The host of a solidarity event in Wallmapu or Europe would feel responsible for providing a shared meal for everyone before or after a political event. The importance of sharing that moment was expressed to me in the context of the trial against Mapuexpress in July 2017. After the trial, all the supporters came together for a meal and I was warned that it would be rude to reject the invitation, to come only for the trial, or to leave before everyone has eaten. This means there is even a (sometimes rather unspoken) demand for and morality in the practice of coming together to eat. ${ }^{7}$

Beyond the praxis of eating together, the transmission of knowledge about food and its preparation is crucial to the contemporary recreation of Mapuche cultural practices mostly carried out by Mapuche women. In that way, they "enact private and embodied politics of resistance against cultural absorption.” (Becerra et. al. 2017, 13) 
Furthermore, the ways meals are shared is given a particular meaning. In my visit to the community of Llaguepulli, I wanted to know what kind of practices and encounters with non-Mapuche the community members perceived to be valuable and positive. On two occasions, good relationships with non-Mapuche visitors to the community were emphasised by having begun through shared meals. Cecilia Necul says that she expressed surprise that the visitors "also wanted to eat with us" (interview with the author, March 10, 2016) as a sign of mutual appreciation. Another conversation told the story of a non-Mapuche family who developed a good and trusting relationship with their hosts, Selma and Ramón Necul. According to them, the mutual trust was expressed by the fact that both families started to have meals together at the same table (Selma and Ramón Necul, interview with the author, March 11, 2016).

Eating together can be interpreted as a way of incorporating a guest into the intimate cultural praxis of the ngvtram, a family conversation. But it is further an occasion wherein an immaterial and material exchange takes place. Sharing a meal becomes a ritualised practice between strangers, where the guest is treated as if he or she were a friend: "Sharing the food and the food [itself] are the currency" and "if I serve you, then you are the debtor. You owe me" (Fernando Díaz, interview with the author, March 26, 2016). But the act of eating together can also be a symbol for an already established trusting and intimate social relationship: for example, on one occasion (a meal, of course), I was introduced to the Mapuche notion of mizawvn, which describes the situation of when two (or more) people eat from the same plate as an expression of enormous trust.

Sharing food is thus a highly important metaphor not only to express how solidarity is enacted or the act of eating itself; it also highlights a critical praxis through which socially binding, long-term relationships between non-Mapuche and Mapuche are produced as a form of compromiso or fortified in the case of mizawvn. It is through this metaphor that solidarity in the present case ceases to be a relationship between two different groups that came together through a political purpose and gradually transforms the political encounter into social solidarity. However, whilst sharing food is a very concrete and vivid metaphor for a practice of solidarity, the importance of sharing and exchange itself deserves some attention as well. 


\section{Solidarity as Compartir: (Critical) Practices of Sharing in Solidarity}

Sharing food transforms the ways in which the involved actors come together, but the crucial aspect of this practice lies in the sharing and not necessarily in the food. Thus, the transformative potential of encounters of solidarity lies in practices of sharing and exchanging material and immaterial goods. Weaving the solidarity network produces an infinite number of encounters of solidarity in which different actors come together and share their experiences. This dynamic was described in Spanish as compartir experiencias, in which actors encounter each other on the basis of a political solidarity but might transform their relationships into social solidarities.

First, the notion of compartir deserves some attention. I was puzzled when my Mapuche interview partners put more emphasis on solidarity in the form of sharing experiences rather than concrete political actions. For example, as a central aim of the encounters between Wallmapuwen and international actors, Isabel Cañet highlights the idea of "sharing experiences and points of view and insights about the political work and experiences of progress" (interview with the author, February 24, 2016). In my perspective, compartir can include different notions: it can mean the act of sharing the same thing equally, sharing different things (exchange), or just spending time together and hanging out.

Compartir was also used in other statements to describe a positive relationship with non-Mapuche people based on mutual sharing and exchange both in a material and immaterial sense. In that way, acts of sharing can be described as spending time together, exchanging cultural knowledge, or exchanging gifts (Cecilia Necul, interview with the author, March 10, 2016). It is important that the three meanings of compartir-sharing, exchange, and spending time together-work together in the transformation of a relationship and would even, in the words of María Teresa Loncón (interview with the author, March 3, 2016), "reaffirm the compromiso" between strangers.

In that way, compartir becomes an indicator of the quality of the relationships produced through transnational advocacy or solidarity action. For example, Alex Mora laments that there are some people in the European solidarity network who are active but "do not get together with each other" and "are isolated, trying to keep themselves at a distance" (interview with the author, November 28, 2015). On the other side (especially in sociocultural events of the Mapuche diaspora like the wetripantu) are moments of compartir, "where we get together and there are all kinds of organisations, they come to get to- 
gether, get to know each other, see each other, talk to one another" (Ibid.). In that way, the notion of compartir has an intrinsically sociocultural dimension that is not only connected to but rather inseparable from political solidarity efforts.

Moreover, several non-Mapuche appreciated the possibility of compartir (i.e., spending time and getting together) with Mapuche. For instance, Peter describes these moments as "something slightly exceptional" and feels honoured since, according to him "they do not do that with everyone" (interview with the author, December 1, 2015). Solidarity projects or transnational advocacy thus create such situations in which non-Mapuche actors might "by happenstance slip into" these moments in which they "just hang out with them" (Ibid.).

This appreciation of spending time together is reciprocated by the addressees of solidarity. Frida Erazo from the Pastoral Mapuche appreciates that a delegation from Adveniat "shared time with the communities, but above all [...] with the family" (Pastoral Mapuche, group discussion, April 6, 2016) during their visit to Chile. To her, the Adveniat delegation was able to "visualise the fruits of their support" (Ibid.) by spending time with the beneficiaries of their donations.

After understanding the notion of compartir, it is worth looking more concretely at what is actually being shared. This is because besides the meaning of compartir as spending time together or hanging out, it also expresses the exchange of goods and gifts, space, and knowledge. Gift or good exchange is a fundamental aspect of the practices within international solidarity with the Mapuche. I rarely experienced an encounter amongst Mapuche or between Mapuche and non-Mapuche activists that did not involve bringing a gift to the host. Such goods are rarely valuable, but are rather tokens of appreciation by the guest in order to symbolically reciprocate the hospitality, value the opportunity of the encounter, and recognise the effort of receiving someone. In the European context, such gifts were books, sweets, something to eat, or a bottle of wine or beer. But besides its symbolic meaning, such gifts can also be contributions to a household with low resources, for example in communities in resistance. 8

The importance of such gifts as a sign of respecting my Mapuche hosts was underlined to me by my contacts within the Mapuche diaspora in Europe. In Wallmapu, I also learnt that it was important to bring some food 
or mate tea to the political prisoners. Eventually, I learnt of one's preferences and started bringing a particular cake or brand of tea during my visits. Other solidarity activists told me that they were also instructed to bring some gifts to their hosts. Sybille was surprised that the gift is not further commented about and, in her perspective, is taken for granted. Her host even ironically challenged her by complaining that she had brought the wrong brand of tea (interview with the author, June 26, 2016). Furthermore, the exchange of gifts is something that enables a durable and caring relationship between the (Mapuche) host and the (non-Mapuche) guest (Cecilia Necul, interview with the author, March 10, 2016).

It is important that these gifts are adequate to the context in which they are exchanged, for example, they are not too expensive or too insignificant. More expensive gifts are especially problematic because they complicate the possibility to reciprocate and contribute to an unequal relationship, undercutting the possibility for an equal devolution- "thus does mutual aid slip into inequality [and] [t]hus do patron-client relations come into being" (Graeber 2011, 119). Such inequality contributes to a paternalistic relationship 9 because they are forced into a position of debtors; in order to reciprocate, they would have to enter in a relationship of subordination (Fernando Díaz, interview with the author, March 26, 2016). This is why, for example, excessive monetary donations were directly rejected (José Luis Calfucura, interview with the author, February 16, 2016b)

Compartir also includes sharing spaces of encounters. The gifts by the guests thus reciprocate the invitation to the host's space. Sharing spaces is also a symbolic act and is linked to the importance of the territory within Mapuche cosmology and political thought. In that perspective, inviting a nonMapuche to a Mapuche territory becomes a meaningful act because of the spiritual and cultural connections associated with certain locations. It also means to share one's community, which is the basis of the rural Mapuche political, social, and cultural life. On a smaller scale, my hosts have shared

For example, in the 1960 s and ' 70 s, right-wing landlords corrupted Mapuche communities by paying for a huge barbecue for everyone. The community felt an obligation to pay them back by voting for the right-wing candidate (Vicente Painel, interview with the author, March 3, 2016). Also, today monetary donations and credit from state agencies are considered very critically (Mauricio Vergaras, interview with the author, February 25,2016 ). Moreover, I was given examples of private companies who basically paid off Mapuche communities for their support of, for instance, a hydro-electric powerplant in their area (Rubén Sanchez, interview with the author, March 1, 2016). 
their houses with me-their most intimate space-and introduced me to their whole family, including their animals. In addition, there is a meaning attached to sharing the same table whilst eating as part of the family conversation ngutram.

Sharing spaces can also have a political function by providing encounters of different political struggles, in which political and sociocultural differences, as well as commonalities, can be articulated. For example, Llanquiray Painemal explains that by sharing the same space in Berlin, different diasporic groups came together and learnt about their different histories, whilst also "looking for a connection with other struggles" (interview with the author, June 16, 2017). Thus, sharing spaces is a meaningful practice in the context of international solidarity, as it is an opportunity for different actors to encounter and connect with each other. They might not share the same vulnerability and positionality, but through sharing the same space, for example within a Mapuche community in resistance, they can experience the material immediacy of repression at a particular moment. ${ }^{10}$ Sharing space thus can serve both to find commonalities in political struggles and at the same time create opportunities for non-Mapuche to empathise with feelings of vulnerability.

A third interesting expression of compartir is the sharing and exchanging of knowledge through international solidarity. To start with, several nonMapuche actors admit to having benefitted from their engagement by acquiring knowledge and learning new things. They describe the activists of the Mapuche diaspora as mentoring the non-Mapuche in solidarity and advocacy action (Amanda, interview with the author, July 1, 2016). Learning new things is also articulated as a central motivation to get involved with solidarity action in the first place. For example, visiting solidarity events serves as a contribution to their academic curriculum (Rike, interview with the author, May 27, 2016; Verena, interview with the author, December 6, 2015). At least Isabell (interview with the author, June 9, 2016), who is from an Indigenous and human rights advocacy organisation, recognises the unpaid labour of the Mapuche diaspora in educating non-Mapuche activists, sharing information, and contributing to their knowledge.

10 I remember vividly the discomfort and vulnerability I felt whilst visiting a Mapuche community in resistance and looking at the sky and seeing a drone flying above or jumping out of the way of an excessively speeding armoured police car. 
Yet Mapuche actors also claim to benefit from the educational and knowledge exchange within international solidarity. For example, Jaime Huenchullán sees in education an "important issue that also should be worked on" (Radio Mapuche 2015). Such experiences would include both the support of educational efforts within his community as well as the solidarity tours by his community's representatives. ${ }^{11}$ For him, the exchange of "solidarity and exchange of experiences has been reciprocal," because "[o]ne has learnt a lot and also the people who came here have learnt with us" (Jaime Huenchullán, interview with the author, March 20, 2016). At the same time, he articulates an awareness about the fact that international non-Mapuche actors have benefitted from the knowledge the community produced "as a product of the struggle" (Ibid.).

The exchange of knowledge also benefits the political efforts of Mapuche organisations and communities by sharing experiences of political strategies and mobilisations (Isabel Cañet, interview with the author, February 24, 2016). For Isabel Cañet, there must be a "redistribution in terms of knowledge and experiences" by international solidarity actors, because "it interests us a lot to get to know the experiences [of others] and [...] people who can come here and also share experiences in terms of participating in the process of revitalising the language [...]"(Ibid.).

Educational exchange is also articulated as a central element of the diasporic experience of some of my interlocutors. For example, Alex Mora claims to have "learnt to see to what we are subjected to" and says, "it is like opening your eyes, like an incredible thing, like living here you start seeing your rights" (interview with the author, November 28,2015 ). In addition, Llanquiray Painemal stresses that she learnt a lot by connecting with the struggles of other diasporic groups in Berlin as a process of "enrichment" (interview with the author, June 16, 2017).

Rayen Kvyeh, who was a political refugee in Germany in the 1980s, had a similar experience. For her, "Germany was a source of knowledge" and through her engagement in the internationalist journal iz3w in Freiburg, she suddenly had access to "a world of political, social, historical, cultural knowledge of

11 Another example would be an educational exchange for young community members in order to study abroad. These young people should then "become an element of the struggle [...] and, if it happens, it would be good if they put this preparation at the disposition of their people afterwards" (Jaime Huenchullán, interview with the author, March 20, 2016). 
Africa, of Europe, Arab countries, India, America" (interview with the author, March 1, 2016). On an interpersonal level, she appreciated the opportunity to have this "contribution of knowledge" from "the comrades" (Ibid.). She also notes that she appreciated the opportunity to learn about different ways of knowing the world. For example, in Germany, she was astonished by "an almost mathematical analysis of the things you could say are scientific" (Ibid.). Thus, her mixed background in cosmologies is something she is thankful for.

These experiences seem to indicate that both non-Mapuche and Mapuche benefit equally from the dynamic of sharing and exchange. Nevertheless, compartir can also turn into a highly exploitative relationship and reinforce a racialised and geopolitical North-South divide, in which certain privileges and resources are distributed unequally. Such exchanges can have an exploitative dynamic, ${ }^{12}$ in which non-Mapuche actors unevenly benefit. This is why the different modalities of exchange and sharing need to be discussed critically by asking whether they constitute exploitative or reciprocal-that is, mutually beneficial-relationships.

Chapter six already discussed some expressions of an exploitative relationship between Mapuche and non-Mapuche, where the latter transform Maputhusiasm into a commodity for their personal benefit in forms of donations or reputation. This exploitative dynamic is a consequence and materialisation of paternalistic attitudes by non-Indigenous people.

In a different context, Amina told me how Sybille was perceived by a visiting Mapuche delegation. Whilst Amina describes her relationship with members of the delegation in positive terms, they did not accept Sybille in the same way. Amina (interview with the author, November 27, 2015) explains that-unlike Sybille-she had never used her engagement in solidarity action to publish something by herself and did not "make that my project" (Ibid.). Her story shows that the Mapuche delegation morally opposed the fact that sybille profited from their relationship. In contrast, Amina did not appropriate the value produced in the encounters of solidarity.

This example highlights that there is not only an awareness of, but also consequences for, such exploitative dynamics. In this vein, Alex Mora argues that there is a need for "more control" within the solidarity rhizome, since "you cannot make money with pain. [...] There are people who have good intentions at the beginning but afterwards you realise that there are profit inquestion of morality. 
terests and they also take advantage" (interview with the author, November $28,2015)$. Controlling the setting of international solidarity in Europe thus reveals itself as a reaction of the Mapuche diaspora against possible exploitative dynamics.

In the interviews with non-Mapuche solidarity actors, I specifically asked who they think benefits from their particular project. Most of the answers reflected an uncanny awareness about the possible exploitative dynamic and their disproportionate benefit within solidarity action. For example, Peter laments that after he had filmed his documentary in a Mapuche community, "they were suddenly left alone" (interview with the author, December 1, 2015). He describes it as "awful" to imagine that some foreign people spend one week with you, document your life, and suddenly disappear without knowing what they are going to do with that material. Regarding the question of who benefits, he considers it "pretty difficult to define without anyone being disappointed" (Ibid.).

Other statements expressed a discomfort of being perceived as "sensation-seeking" and about the possibility of Mapuche people feeling as an "object of study" (Clarissa, interview with the author, January 22, 2016). Thus, there seems to be an awareness about the fact that encounters of solidarity reflect and reproduce power imbalances because "that feeling might come up, 'someone comes from outside, has read some books, and thinks that $\mathrm{s} /$ he somehow can talk to you, and, yes, maybe they change something and maybe they don't, but, yes, these people will have done their job and leave" (Madelaine, interview with the author, December 6, 2015).

I interpret these statements as reflections about the possibility of reproducing an exploitative dynamic within solidarity action based on the existing power imbalances within a particular encounter. Such encounters produce situations that non-Mapuche activists describe as uncanny, absurd, or discomforting and in which they are worried that their actions might have negative consequences for the Mapuche.

Decolonial interventions have already criticised the exploitative dynamic of non-Indigenous and Indigenous relations within encounters of solidarity. They particularly address the unequal exchange (exploitation) in knowledges as part of a "critique [of] the imperialistic enthusiasm for 'getting to know the Other' as one-way sharing that benefits only non-Indigenous people" (Land 2015 , 119). The interest of non-Mapuche actors in learning from the Mapuche 
thus transforms the latter into native informants ${ }^{13}$ without reciprocating the knowledge transfer. Based on such decolonial interventions, sharing knowledge is much more than the exchange of information; instead, it is based on a social dimension between the interlocutors which demands a respectful and dialogic-that is, reciprocal-relationship.

Mapuche actors have challenged such experiences of exploitative dynamics within solidarity action further by demanding a fair redistribution. They hereby argue for a more reciprocal or redistributive dynamic within solidarity as compartir. This idea was also proposed by Isabel Cañet, who insists on a "redistribution in terms of knowledge and experiences" (interview with the author, February 24, 2016), and by Nadia Painefil, who criticises researchers who do not leave "a redistribution of what they investigated" (interview with the author, March 10, 2016). The idea of redistribution is interesting because it shows a clear awareness of the fact that non-Mapuche people benefit from these encounters and, accordingly, demands repayment. It further challenges the illusion that there actually might be a horizontal exchange within relations of solidarity that are clearly unequal.

Several stories demonstrate how a redistribution or devolution between Mapuche organisations and communities and solidarity activists might take place. For example, Alex Mora notes that he started to support "the Mapuche movement by taking photographs" but "handed over all the material" (interview with the author, November 28,2015$)$. Such accounts include promises, as Sybille (interview with the author, June 26, 2016) explains, "that all of them will get a piece" of the final product, in that case a photography documentary about Wallmapu, by "bringing pictures from the first trip to the second and distributing them to everyone I see." In short, her idea was "to carry the whole project back to Chile".

Practices of redistribution and devolution within solidarity action are not given but demanded as a condition by Mapuche actors to agree to support a certain project. This situation sometimes created irritation amongst the nonMapuche actors. For example, Peter was puzzled when some of the commu-

13 A decolonial critique of the native informant, in contrast, argues that "an interview, for instance, is not just a means to obtain data." Instead, "it is a visit in which the interviewer is a guest in someone else's memories and in someone else's mind. A most respectful and ritualized dialogic relationship needs to be forged before such an exchange may even take place. If we were to engage decoloniality strictly on careerist grounds, it would lack a moral center" (Arias 2018, 618). 
nity members demanded a copy of the finished documentary or "from time to time [...] wanted some things from us" (interview with the author, December 1, 2015). In contrast, I would like to ask why they should not demand things in return. It seems that the community is clearly aware that they also should benefit from the project in some way.

Such demands of Mapuche communities reflect their experience of supporting a certain project or handing out information. Today, there is "a lot of distrust also in the fact that sometimes you [the Mapuche] give out information and then it does not come back" (Isabel Cañet, interview with the author, February 24, 2016). We went deeper into the topic of redistribution in our conversation and she began to demand redistribution from me as a non-Mapuche researcher. She directly suggested ways of how Wallmapuwen could make use of and share my research results. Her statement started by acknowledging me as a researcher and my investment in the extraction of knowledges. But continuing, she proposed some kind of deal between us, in which she would give me an interview on the condition that I redistribute some of the material (Isabel Cañet, interview with the author, February 24, 2016).

In a similar way, my interview partners in the community of Llaguepulli discussed and demanded redistribution from me. In these situations, I was directly challenged on "what contribution" I would be able "to leave to the community" (Cecilia Necul, interview with the author, March 10, 2016). It was suggested I "send notes [...] by internet or fax" or contribute "with some sort of little book" for future visitors to the community (Ibid.). Nadia Painefil (from the same community) highlights the educational and political benefit of such forms of redistribution. This is because of a critique that "people give information and then it does not come back here" so that, for example, "many of the regional universities here keep the Mapuche knowledges and they become the owners of Mapuche knowledge" (interview with the author, March 10, 2016). Her father, Luis Painefil, also laments the historical continuity in which many investigations have extracted knowledge but do not provide "any report afterwards, a document, everything they talked about" (Ibid.).

Nevertheless, these statements do not seem to reject the possibility of research or solidarity projects with the community generally, but critically address the terms on which this collaboration is done. For them, there must be a clear and visible benefit for the community, in which the idea of redistribution is only one possibility.

Of course, some solidarity projects do not end up like they were planned. In this way, the possible redistribution or benefit for a community is nonexis- 
tent. Jaime Huenchullán addresses such cases with understanding: "if things did not work out, it is because they just could not be done (pause) and we understood [this]." (interview with the author, March 20, 2016). In contrast and despite such disappointments, he goes on that "[from] all the people [nonMapuche foreigners] that we have met, we are in contact with the majority and some come back or visit us" (Ibid.). This statement reveals something noteworthy: despite failed projects and the disappointments that go along with them, Jaime Huenchullán appreciates the commitment and compromiso of these non-Mapuche actors because they have come back to visit them. He thus gives value not exclusively to encounters of solidarity that concluded in a successful project but also to those that led to an enduring social relationship expressed in ongoing mutual visits. In other words, the political aspect of solidarity becomes secondary to its social dimension.

Juan Fuenzálida goes into a similar direction whilst detailing that he began to understand that within Mapuche cosmology the "relationship comes first" (interview with the author, March 12, 2016). The quality of the exchange within encounters of solidarity then is not just measured according to its exploitative dynamic or possible redistribution. Encounters of solidarity are rather judged by if and how they create a social surplus and relations of social solidarity between the involved actors.

Going back to my experience from the beginning of this chapter, now it becomes clear why Vicente Painel disapproved of Clarissa's behaviour. Despite her possible political solidarity with the Mapuche, she preferred to maintain social relations of solidarity by living with a white Chilean family; she chose their relationship over the ones she had with the Mapuche.

\section{Solidarity as keyuwvn/mingako: The Assemblages of Solidarity}

The final section of this chapter will argue how encounters of political solidarity between Mapuche and non-Mapuche produce and assemble new social bonds, and thus forms of social solidarity. This challenges a basic assumption in the idea of a political solidarity that the involved actors are socially separated and distant. Instead, encounters of political solidarity, for example within transnational advocacy and international solidarity, thus have the potential to transform the social relationships of the involved actors into forms of social solidarity. In short, the political solidarity between non-Mapuche 
and Mapuche demands and, in some cases, creates and assembles, new social bonds.

The idea of assemblages is particularly helpful here because it "allow[s] us to ask about communal effects [of international solidarity] without assuming them" (Tsing 2015, 23). Understood that way, the outcome of international solidarity cannot only be measured by looking at policy, legal, or institutional change, but needs to include the heterogenous and open ways of assembling social bonds of affinity between and across different actors.

Such an assemblage of social and political solidarity is strange for a Eurocentric perspective. I found it hard to make sense of Vicente Painel explaining Clarissa's choice of staying with a non-Mapuche family despite her (possible) engagement in political solidarity. In a similar way, Peter was struck by the fact that the Mapuche community constantly demanded he spend more time with them. For example, "they did not want any money from us. It was more about small, interpersonal moments" (interview with the author, December $1,2015)$. These experiences indicate the value Mapuche actors assign to the social dimension of encounters of solidarity.

Two Mapuche concepts or ideas, keyuwvn and mingako, are particularly helpful to decipher the importance of social and communal bonds for a critical notion of solidarity. A decolonial approach to solidarity needs to go in two directions. On the one hand, it demands a critique of Eurocentric notions of solidarity that inform contemporary solidarity practices, legitimise paternalism, recentre white agency, or reproduce colonial stereotypes. On the other, it challenges to think of solidarity beyond Eurocentric categories and instead based on other cosmological and epistemological notions. The last section of this chapter addresses the latter.

Several Mapuche interlocutors challenge the Eurocentric idea of Western forms of solidarity and proposed notions of solidarity based on a Mapuche cosmology. The most elaborate analysis comes from Rayen Kvyeh, who critically notes that "you [Europeans] have a concept of solidarity which is about helping the poor" (interview with the author, March 1, 2016). She explains the Mapuche idea of solidarity thusly:

Amongst the Mapuche that is not the concept of solidarity. The concept of our solidarity is not the solidarity in a wigka style, as we say. You should not [only] help one because he is poor, right? For example, have you ever been to Chiloé? Well, there you use the mingka, right? [...] You build a house because it is a sentiment, it is belonging, let's say, and everyone participates 
and builds the house. In occidental terms you would call this solidarity, right? But for us it is not solidarity, it is part of life itself. Because you defend the Mapuche prisoners not because of a political conception but because it's part of life. The Western concept of solidarity is when you give something to someone. We do not give something to someone, we share. You share the pain, you share the land, you share the food, you share love, beliefs, the struggle of belonging of being Mapuche-that is solidarity. It is not that you give the other [something]. Mapuche solidarity does not have a price, it does not have a currency. It does not translate into currency. It does translate in facts, in care, in love, in work, in being there. That is solidarity. (Ibid.)

She associates the Western concept of solidarity with paternalistic and hierarchical practices. Instead, in her account, solidarity is part of a belonging to a particular social group and takes place within communal life and as a member of that group. She hereby critiques the ideological motivation for solidarity within theories about political solidarity.

This conversation with Rayen Kvyeh was joined by a machi friend of hers. After the interview, he offered to translate notions of solidarity into Mapuzugun and explain their meaning. He offered the idea of mingako as collective and solidarity work, lofkedaw as communal work, lofdungu as any topic or thing that has a communal importance, norfeleal as having a good time and living well, komkeyuayiñ as mutual help, wherein everyone helps everyone, and finally, wayontamapukeyuaful as international solidarity. All of these notions have an essentially communal and social basis and cannot be detached from the social context in which they take place because they are tied to a specific collective or community. Also, they clearly speak to the moral and affective dimensions of such forms of solidarity.

The cooperative Kvme Mogen also bases its work on Mapuche cosmology as their guiding principles. They argue that the Mapuche notions of keyuwvn, to work amongst everyone, and mingako, collective work in the countryside/community, can be translated to the form of the Western notion of the cooperative (Pérez Guerra 2016).

If we follow the insight of Rayen Kvyeh, this means that in encounters of international solidarity two different understandings of solidarity clash. Vicente Painel understands this in terms of the sociological difference between mechanic and organic solidarity. According to him, "European solidarity is organic solidarity" and "in the case of the Mapuche [...] you maintain a lot of mechanic solidarity" (interview with the author, March 3, 2016). As expressions 
of this mechanic solidarity, he gives examples like the keyuwvn or mingako, but also of the malluntu, which is what Mauss (2013) describes as mutual and obligatory gift exchange. With that anthropological perspective it is now possible to conceive of the "relation-making force of the gift" (Tsing 2015, 123) in such practices between Mapuche and non-Mapuche. Accordingly, this would mean that the Mapuche society is characterised by strong communal bonds and mutual identification, which are perpetuated through an ongoing debt via obligatory gift exchange. On the other side, Western socialisation causes a higher degree of individualisation in non-Mapuche, where there is no need to verify social bonds through gift exchange due to social stratification and labour division.

This differentiation is helpful for understanding statements in which nonMapuche solidarity actors complain about the social distance between German people in contrast to Latin Americans (Verena, interview with the author, December 6, 2015). Such a comment appears to be a critique of the lack of communal bonds and the singularisation within a highly stratified society. Furthermore, organic solidarity also describes the increasing specification and differentiation of labour within Western societies.

Such a contractual understanding clashes with the more mechanic notions of solidarity amongst the Mapuche society, where individual tasks, obligations, and responsibilities are subject to constant negotiation. This is why, for example, Madelaine (interview with the author, December 6, 2015) was puzzled by the idea that her presence might lead to further demands by the Mapuche community. After all, for her, there is an apparently clear division of labour between both parties. In her view, her engagement thus would not further create a mutual obligation that eventually demands certain forms of reciprocation or the establishment of social bonds.

In contrast, the majority of statements from Mapuche interlocutors point towards more mechanic forms of solidarity, in which the social cohesion is given more importance than the individual and is "only possible to the extent that the individual personality merges into the collective personality" (Durkheim 2012, 183; my translation). This kind of mechanic solidarity is not a contractual relationship between individuals but is rather a result of the social bonds within a collective. This is what the Mapuche notions of mingako and keyuwvn embody.

Some experiences and statements within transnational advocacy and international solidarity express such an understanding. For example, the aim of the cooperative Kvme Mogen is not an "individual accumulation" of associates 
but to build a "culture of mutual, solidarity support, that people remember even from their historical memory" like when in a community "a person does some work [for someone and] then that someone does some work for someone else" (Gloria Marivil, interview with the author, February 23, 2016). The cooperation hereby favours an economy of mutual obligations, in contrast to the Western understanding of solidarity as a voluntary act. Thus, as the result of a communal belonging, solidarity implies a mutual obligation and commitment, in which the social bonds are (re)produced.

This further explains why, for example, there is no possibility to donate in Kvme Mogen. Instead, the only option for international support is for nonMapuche actors to become members (Vicente Painel, interview with the author, March 3, 2016). The reason is that a mechanic logic of solidarity demands that the mutual obligation as a basis for mutual support can only be the result of a belonging to the collective of associates. Whilst a donation, according to the logic of organic solidarity, would be the result of an individual choice without a community, in mechanic solidarity support is possible only through adherence and belonging to a collective.

Several statements about compartir reflect this logic of mutual obligation in contrast to individual choices. In that perspective, compartir is not a logic that closes or seals a deal, but it creates and reproduces a debt between both actors who are now mutually obliged to perpetuate their relationship. The creation of a debt thus transforms voluntary acts of solidarity into obligation, expressed in a ritualised, material, or immaterial gift exchange.

This ritualised and obligatory gift exchange in Mapuche society, the malluntu, creates a moral and social surplus, symbolised by the gift (Frank 2016, 263-68). The malluntu is also present in encounters of solidarity between nonMapuche and Mapuche in the various forms of compartir. Sharing spaces and exchanging goods is essentially a form of gift exchange within a mechanic logic of solidarity. Hereby, apparent meaningless small tokens of appreciation resemble symbolically and cosmologically loaded artefacts that create mutual obligations leading towards social bonds. In contrast to the contractual logic within organic solidarity, the gift exchange essentially aims at perpetuating the social bonds (Frank 2016, 274).

Such encounters between non-Mapuche and Mapuche and their underlying gift exchange thus imitate the Mapuche logic of creating alliances with foreigners on the basis of an unstable balance between friendship and enmity. For example, the most important Mapuche ritual, the nguillatun, consists of a series of gift exchanges that symbolically transform enemies into allies (Díaz 
Fernandez 2012, 80). Experiences of compartir within encounters of solidarity thus resemble the dynamics of alliance-making and social recruitment of the Mapuche society (Stuchlik 1999).

In that way, political encounters of solidarity take place according the mechanic logic of solidarity within the Mapuche society. International nonMapuche actors are woven into this social network on the basis of their political engagement and become socially attached to and assembled with Mapuche communities and organisations as a result of their general "openness towards a possible social horizon" (Díaz Fernandez 2012, 69; my translation) with the non-Mapuche world. In contrast to the assumption that organic forms of solidarity slowly overlap mechanic forms, ${ }^{14}$ in that case the social experiences of organic solidarity by non-Mapuche are slowly transformed as they are woven into the social Mapuche networks.

These encounters of different logics of solidarity can, in the worst case, (re)produce relations of domination and exploitation between the nonMapuche and Mapuche societies. This also leaves non-Mapuche solidarity actors puzzled about the different Mapuche solidarity logic, which requires social interaction. In the best case, the encounters through solidarity action actually produce durable and intimate social bonds amongst Mapuche and non-Mapuche actors. Finally, it is not only the possibility of the co-existence of mechanic and organic solidarity that deserves special attention. What is more, those bonds are created following a mechanic logic of solidarity and thus disprove the teleological assumptions about the suppression of mechanic by organic solidarity.

Several Mapuche interview partners highlighted that solidarity in their perspective, whether as keyuwvn or mingako, should be a mutual, reciprocal, and horizontal relationship. ${ }^{15}$ In the Mapuche society, there is a generalised reciprocity that does not immediately expect the return of a gift but demands the general disposition of devolution. In that way, "this disposition towards reciprocity that manifests itself in the form of hospitality, generosity, and that escapes the quick answer in the sense of a 'payment' for a service is what establishes a network of mutual support on which the Mapuche society is built

\footnotetext{
14 Most prominently articulated by Durkheim (2012, 200-255).

15 This is important because mechanic solidarity and gift exchange can also create or deepen hierarchies amongst different actors. In particular, nonmonetary gift exchange is a key factor in developing debts and thus hierarchies within human societies (Graeber 2011).
} 
today" (Díaz Fernandez 2012, 82; my translation). This logic of mutual support also manifests itself within encounters of solidarity with the non-Mapuche world. Notably, its generalised logic of reciprocity demands an equal benefit, or at least the promise of a benefit, of all the involved actors as a responsibility and obligation towards a shared community.

The reciprocal aspect of solidarity implies the disposition of "people helping each other, being in solidarity, having responsibilities as a community" and "that the communities assume the responsibility towards their members, the people" (Llanquiray Painemal, interview with the author, June 16, 2017). It demands a growth that is mutual by "looking for the best balance so that everyone is able to profit" (José Luis Calfucura, interview with the author, February 16, 2016a). Furthermore, representatives of Kvme Mogen articulate the reciprocal aspect of keyuwvn as part of the general Mapuche ethics az mapu (Pérez Guerra 2016). ${ }^{16}$

The reciprocal aspect of solidarity is also present in interpersonal relationships between Mapuche and non-Mapuche. Whilst speaking about her exile in Germany, Rayen Kvyeh (interview with the author, March 1, 2016) constantly puts emphasis on the mutuality and reciprocity of the learning process between her and her German hosts, which benefitted both. These connections later became friendships based on that shared understanding of horizontality.

However, such relations of reciprocity can be corrupted by powerful and resourceful actors from the outside. For example, Chilean institutions have tried to get influence within a community by engaging in the everyday networks of mutual exchange or ritualised practices like the nguillatun. Fernando Díaz describes such attempts as akin to "a virus entering a network" (interview with the author, March 26, 2016), since the hierarchical logic of the state would destabilise the principle of reciprocity within the Mapuche society. However, as long as external actors respect the autonomy of their society and do not try to co-opt their decision-making processes, an external support that is sensitive to the principle of reciprocity would not be destabilising (Ibid.). In short, as long as it is on a reciprocal basis, international solidarity is welcome.

16 Specifically, it was described as the creation of something that is owned collectively without being indebted to anyone (Cloria Marivil, interview with the author, February 23, 2016), the formation of an alliance with others in a situation of equality (Ibid.), and a system of saving and mutual loans for members of a community (lbid.). 
Mutual support is conceptualised as a horizontal form of solidarity that does not (re)produce social stratification, but rather reinforces balanced and equal social relationships. Horizontal support and solidarity would mean "building a world where everyone has a place, where you have a place, where the other comrade has a place, respecting each other, and also, sure, learning relations of horizontality" (Llanquiray Painemal, interview with the author, June 16, 2017). In addition, transcultural communication and translation should include horizontality and allow mutual critique (Ibid.) in order to strive towards an "equilibrium in the discussion" and "to have the same opportunities to discuss amongst equals" (Rayen Kvyeh, interview with the author, March 1, 2016).

Communicative horizontality is also a central demand of the contemporary Mapuche organisations towards the Chilean state (Mauricio Vergaras, interview with the author, February 25,2016 ). This is because until the present day there has been no horizontal basis for a political dialogue between Mapuche society and the Chilean state. Such a demand for horizontality is equally present within international relations of solidarity with the Mapuche, as an expression of their cultural politics of autonomy.

From Mapuche perspectives, relations of solidarity are conceived as a perpetual, long-term and intimate social and political commitment. Whilst visiting a Mapuche community in resistance during my trip to Wallmapu, I had the chance to discuss solidarity with a local community leader. For him, solidarity of non-Mapuche people would mean that they walk together with the Mapuche-caminar juntos. I interpret the idea of walking together as a form of expressing the temporal as well as the spatial dimension of solidarity. It expresses, on the one side, the sustainability and longevity of solidarity and, on the other, the proximity, closeness, and intimacy of people engaged in solidarity. Ultimately, it also expresses a clearly ethical and social quality of solidarity relations.

The appreciation of a long-term commitment is the other side of the coin that sanctions and denounces a short-term commitment or the privilege of leaving. ${ }^{17}$ For example, Juan Fuenzálida notes that during his first ten years in Tirúa, there was still a lot of distance between the JMM and the local Mapuche communities. Especially after the seaquake in 2010 and the devastation in the region, the local communities expected the JMM to leave soon. According to Juan Fuenzálida, the fact that they stayed finally led the communities to

\footnotetext{
17 See chapter six.
} 
bestow their trust upon them. This is because, according to him, their logic is that "if you are not coming to stay, you better not come in the first place!" (interview with the author, March 12, 2016).

This temporal logic of a sustainable solidarity is what measures the commitment, responsibility, and liability of non-Mapuche solidarity actors or organisations. For example, they express an awareness to "show [their] presence" in a Mapuche community in order to "show that we still exist as a group and we still work reliably, and we want contact with you" (Amina, interview with the author, November 27, 2015). The demand of sustainable forms of solidarity is made explicit by claims that "it is necessary that the international solidarity [...] is continuous [...]"(Jaime Huenchullán, interview with the author, March 20, 2016).

The long-term commitment of solidarity also includes the sustainability of the social relations forged in solidarity action, which are measured according to their durability. Positive examples of relations of (social and political) solidarity are those where "you keep in touch and someone comes back" (Ibid.). ${ }^{18}$ In contrast, if you do not stay in touch and "if you forget to write an e-mail, if you forget to call me, you forgot what it means to cultivate a friendship" (José Luis Calfucura, interview with the author, February 16, 2016a). Also, rejecting the possibility of a sustainable commitment or invitations to stay longer might cause disappointment and frustration for the Mapuche hosts and expresses the non-Mapuche guests' privilege of leaving (Peter, interview with the author, December 1, 2015).

This means that durable relations of solidarity create the possibility of friendships between Mapuche and non-Mapuche, making those relations more binding and enjoyable (Amina, interview with the author, November $27,2015)$. Friendship and trust are described as possible results of a longlasting relationship that might have a starting point in the mutual or even just unilateral interest by non-Mapuche in engaging in solidarity action.

Decolonial interventions have also critiqued experiences of solidarity between non-Indigenous and Indigenous people without a long-term commit-

18 A similar idea was expressed in the community of Llaguepulli about experiences of keeping in touch with former non-Mapuche visitors that would even transform them into family members (Cecilia Necul, interview with the author, March 10, 2016). Also, when asked how to describe these good types of relationships with non-Mapuche people, Nadia Painefil characterises them "as friendships, like staying in contact, they always write us" (Luis and Nadia Painefil, interview with the author, March 10, 2016). 
ment (Land 2015, 166-69). This is because an antiracist or decolonial commitment "requires that white subjects inhabit the critique, with its lengthy duration, and [...] recognise the world that is re-described by the critique as one in which they live" (Ahmed 2004, para. 57; emphasis in original). This lengthy duration and demand for sustainable relations of solidarity is expressed, in the present context, by the reciprocal and horizontal logic of solidarity which creates an "infinite sequence of exchanges" and thus "involves a nexum" (Frank 2016, 274; emphasis in original). The idea of solidarity as walking together makes this demand for a continuum within solidarity visible.

Coming together in encounters of solidarity and compartir is a central aspect of solidarity practice with the Mapuche. These situations make intimate and close encounters between non-Mapuche and Mapuche actors possible. Based on the previous arguments, such encounters of interpersonal proximities could be considered an aim in itself of international solidarity by transforming political solidarity into social bonds. The idea of interpersonal relations as an end in themselves resonates in the famous statement by the Chilean singer and artist Violeta Parra. When asked what artform she preferred, she answered that she would always choose to stay with the people (Alex Mora, interview with the author, November 28, 2015). To paraphrase her, solidarity in the present case is choosing to stay with the people.

During my research, I slowly began to understand that such face-to-face encounters are a fundamental aspect of transnational advocacy and international solidarity. I learnt about its importance in countless situations in which I would just sit around with other (Mapuche) people before or after a political event, drinking tea, having a conversation, or laughing together. And, for example, if you have not yet shaken someone's hand, there would hardly be an interaction at all.

Numerous statements from interviews with non-Mapuche and Mapuche people alike highlight the importance of interpersonal encounters as an end in itself (The Hague, group discussion, May 5, 2015). Such moments produced a rewarding feeling of encountering people (Rike, interview with the author, May 27, 2016) or established contact in the first place (Ibid.). In these situations, Sybille experienced the "true communities" and "a totally different community spirit than amongst non-Mapuche" (interview with the author, 
June 26,2016 ). The interpersonal proximity or contact is thus a key factor in establishing contact or accessing a Mapuche community. ${ }^{19}$

My experience of meeting Jaime Huenchullán in Cologne as a preparation for my visit to Wallmapu highlights that aspect as well. I understand this experience as an example of the need to encounter someone personally before a relation of solidarity could be possible. Still, besides these direct encounters there is also the possibility of being welcomed by knowing a person who already has a trustful relationship with the community. ${ }^{20}$

Knowing someone or visiting someone through a recommendation thus grants or denies access to Mapuche contacts. Other non-Mapuche activists had similar experiences, in which knowing someone was described as a precondition for the visit (Sybille, interview with the author, June 26, 2016). Through the mediation of a third person, non-Mapuche actors become woven into the solidarity network as a result of social and interpersonal bonds. Such face-to-face encounters also reflect the reliability and commitment of the non-Mapuche actors. For example, Eva notes that she wanted to install her project in another Mapuche community. That community declined because Eva was not able to spend some more time in the community and thus did not "really get to know the community life" (interview with the author, January $29,2016)$. It is through proximity and intimacy that different realities, separated by privilege, encounter each other. Whilst such encounters make these hierarchies visible, they also provide a space to seek possible commonalities (Llanquiray Painemal, interview with the author, June 16, 2017).

Such an emphasis on the need for interpersonal closeness and proximity challenges understandings of international solidarity as relations of distance and with only a little face-to-face contact (Gould 2007, 157). Proximity and closeness in interethnic contact has a productive and transformative dimension and can lead both to the maintenance but also to the deconstruction of stereotypes and racial prejudices (Hamann and Karakayali 2016, 84; Land 2015, 153; Usbeck 2015, 210). In any case, they produce "domains of commonality"

Nevertheless, they have also been exploited by non-Mapuche actors by placing certain individuals known to a community, and sometimes even Mapuche, as intermediaries between themselves and a particular community (Rubén Sanchez, interview with the author, March 1, 2016).

20 In that way, unknown people would be welcome on the basis of an already established connection and as a someone's 'plus-one.' Jaime Huenchullán explains this logic to me whilst detailing that someone could visit Temucuicui on the recommendation of "Sebastian from Germany" (interview with the author, March 20, 2016). 
(Glick Schiller 2016, 7) that might be created through a "democracy of proximity" (Kristeva quoted in Squire 2018, 130), as a consequence of the "shared production of space" (Lefebvre quoted in Purcell 2003, 577).

Walking together in solidarity through proximity contains an ethical principle for solidarity since the "empirical immediacy of two human faces confronting each other [...] appeals to the political responsibility of the Other and requires the overcoming of the horizon of Totality (the 'going outside of the path' that has been established)" (Dussel 2006, 81; emphasis in original). At the same time, face-to-face encounters and the proximity of social relations are a crucial aspect of the mechanisms of social recruitment within Mapuche society (Stuchlik 1999). Here, contacts and bonds are created according to the social, familiar, and spatial distance amongst people. This distance or closeness then obtains a "logical priority to the analysis of interpersonal relations of the Mapuche" (Ibid., 24; my translation). In the present case, a similar logical priority must be given to the interpersonal relations between Mapuche and non-Mapuche within encounters of solidarity.

Critical practices of solidarity like compromiso and compartir connect different actors and communities by transforming or (re)creating social bonds between them. Solidarity then takes place from within these newly established bonds as a form of mutual and communal support under the logic of reciprocity and horizontality. This type of solidarity demands a temporally sustainable and spatially intimate and close relationship. Hereby, the initial political relation of solidarity is transformed into social solidarities of different kinds.

In order to make sense of the very heterogenous and open-ended new relationships that are forged through solidarity, it is best to describe them as assemblages of solidarity. Accordingly, solidarity is assembled as forms of identification, recognition, belonging, mimesis, family, and friendships. I propose the idea of assemblages of solidarity because, first, an assemblage is a momentary product of a very particular and contingent relation within the rhizomatic solidarity network. Second, it is a partially autonomous relation within a wider networked structure, but is not determined by it. That means that specific social bonds can be (re)created and coexist with other forms of relationalities within the same structure. Third, the idea of assembling solidarity grasps the creative and transformative character of relations of solidarity. Finally, the idea of an assemblage highlights the possibility of human/nonhuman encounters, which in the present case could mean establishing rela- 
tionships between non-Mapuche actors and the non-human environment in Wallmapu as part of an ecological cosmopolitanism from below.

Mechanic forms of solidarity demand a considerably higher degree of mutual identification than organic forms. Some theoretical debates about political forms of solidarity also preclude shared identification as the basis for solidarity, whilst others have criticised their identification-based conceptualisation. In accordance with the latter, identification can be understood rather as a product of relations of solidarity instead of their condition.

Social proximity and closeness were described as enabling an identification with the vulnerability of the Mapuche; sharing and identifying with that vulnerability was detailed as a major motivation for engaging in the struggle or solidarity activism (Radio Mapuche 2015; Alex Mora, interview with the author, November 28,2015$)$. More interestingly though, non-Mapuche actors claimed to be able to identify more with the Mapuche as a result of the social proximity produced through solidarity action. According to Amanda, for example, "you become more involved because they tell you their personal story and it gets to you, or at least to me, on an emotional level" (interview with the author, July 1, 2016). A major challenge of transnational advocacy and international solidarity is creating empathy by identifying with an oppressed or persecuted group (Maike, interview with the author, June 9, 2016). Nevertheless, this approach needs to be attentive to "imperialist ways of addressing difference [by] trying to erase or negate difference" (Land 2015, 120).

Still, sustainable and intimate relationships of solidarity can provide a basis on which non-Mapuche might be able to identify with the vulnerability and struggle of the Mapuche. This identification, nevertheless, needs to be a performative result of concrete practices and commitment instead of a nonperformative claim. One of Sybille's experiences makes this passage from nonperformativity to performativity tangible. After a demonstration where she had been taking pictures, she was invited to participate in a social and spiritual gathering of a community. In that context, people asked her not to take pictures but allowed her to participate in the festivities. Whilst she was frustrated at the beginning that she could not take photographs, during the festivities she became more and more involved and was "so moved [...] by the warmth" that she "almost forgot" about taking pictures. She concludes that "those are the best moments, in which you realise [...] that you actually just want to continue to participate" (Sybille, interview with the author, June 26, 2016). 
On the other side of the emotional spectrum, identification can also surface through shared vulnerability. During my research in Europe, I had visited many demonstrations and gatherings in solidarity with the Mapuche, but the first rally after my return from Wallmapu felt very different. This was because in my last two weeks in Wallmapu I had visited a community in resistance and stayed with the community's werken, whom I had previously met in Europe. I spent a couple of nights at his family's house and I enjoyed the visit a lot. The day after I had left, I woke up and had some missed calls from Fernando Díaz from early in the morning, who knew that I was visiting that particular community. When I called him back, he sounded extremely worried and asked me if I was OK. I answered affirmatively and asked what was going on. Then he told me that last night the same community I had visited was raided by the military police and that several community members, amongst them those I had talked to, were arrested. I was shocked and could hardly believe that the people who had just hosted me were in prison. Whilst talking to Fernando Díaz, I also realised that if I had stayed one day longer in the community, I might have been arrested as well. As international visitors in Mapuche communities in resistance are generally treated as supporters of terrorist activity and are expelled from the country, in short, it could have ended pretty badly for me.

After coming back to Germany, I went to rally against this raid and the imprisonment of those community members. It came as great shock when I realised that I was protesting as someone who was almost affected by this event himself. The rally felt much more intense, important, and relevant than any other demonstration I had been to before. My participation in that rally and my commitment felt different, because "to be committed is to be in danger" (Baldwin quoted in Yancy 2018, 116). It seemed that in the end I could identify with the cause of the Mapuche because I felt a glimpse of the same repression that communities in Wallmapu face constantly. My encounter with the community in Wallmapu thus transformed my perspective about their vulnerability and opened a window towards identifying with the Mapuche. This is because, as a result of compartir with those community members, it actually could have been me.

In discussions in moral and political philosophy, solidarity has been conceptualised as a form of recognition. But practices of recognition in the present case are rather different to these conceptualisations of a moral solidarity. To begin with, Fernando Díaz notes that the Mapuche communities rejected the unilateral recognition by the JUPIC. According to him, this is 
because "the Mapuche said to us that they do not want the word 'pastoral' and that they are not sheep" and they "realised that there was a complaint regarding this subject-object or agent-patient relationship and instead [there was a demand for] teamwork." Instead, they engaged in horizontal and reciprocal relations with the communities by "walking together" with them (Fernando Díaz, interview with the author, March 26, 2016).

Also, the conversations with non-Mapuche actors indicate that recognition does not reveal a moral positionality towards the Mapuche but, in contrast, of the Mapuche towards them. For example, some report that nonMapuche actors and their solidarity efforts have not been recognised by the Mapuche because they did not create a social bond with them and were perceived as only pursuing their own interests (Amina, interview with the author, November 27, 2015). Others had the impression that their Mapuche hosts perceived them as "quite alright" (Peter, interview with the author, December 1,2015 ) or received "a real recognition for the courage" of visiting them (Greta, interview with the author, December 12, 2015). In addition, Amanda seemed to strive to be recognised as "genuine" in order to be "able to do something really meaningful" (interview with the author, July 5, 2016). For Verena, it seemed important to "be integrated more and more in the group" and to become "incorporated" (interview with the author, December 6, 2015) within a solidarity activity in Europe.

Being accepted and recognised as a Mapuche and a solidarity activist was also discussed as an important aspect in statements of diasporic Mapuche in Europe. On the one hand, it is vital to become accepted as a Mapuche within the diasporic network in Europe (Alex Mora, interview with the author, November 28, 2015). On the other, diasporic Mapuche struggle to be recognised as a Mapuche by communities in Wallmapu since they grew up in a different context (Andrea Cotrena, interview with the author, June 6, 2017). Being accepted as a member of a transnational Mapuche society thus seemed to be more relevant than being recognised by non-Mapuche.

Very much on the contrary, non-Mapuche become recognised as solidarity activists, for example, by respecting the authorship of cultural (José Luis Calfucura, interview with the author, February 16, 2016a) or political ideas (Isabel Cañet, interview with the author, February 24, 2016), as well as their political efforts and struggle (Jaime Huenchullán, interview with the author, March 20, 2016). Non-Mapuche actors are accepted and recognised as those who "[are] human and [have] reflected about a lot of things and keep reflect- 
ing and keep learning" (Llanquiray Painemal, interview with the author, June 16, 2017).

In this way, recognition in this case of solidarity is demanded according to a reciprocal and horizontal logic. This is also the case in relations between the Mapuche society and the Chilean state. Here, the Mapuche society rejects the possibility of a unilateral recognition by the state as long as the state does not recognise the autonomy of the Mapuche (which would include their right not to recognise the state). This reciprocal notion of recognition complicates debates in moral philosophy, which conceive it as a unilateral relation.

This analysis suggests, instead, that the possibility of solidarity does not depend on a one-sided recognition, but rather on one that is mutual, reciprocal, and horizontal. In Chilean-Mapuche relations there is a lack of recognition by both sides. In this way, the discussion about recognition with international non-Mapuche activists is insightful because it provides examples and experiences of a mutual recognition between Mapuche and non-Mapuche. Furthermore, the statements from above show that the much more interesting question is whether the non-Mapuche activists are accepted and recognised by the Mapuche within opportunities for solidarity.

Relations of solidarity between Mapuche and non-Mapuche create social bonds assembled as forms of belonging. ${ }^{21}$ I experienced the possibility of such a transformation on a discursive level when diasporic Mapuche activists slowly began to call me peñi, the Mapuzugun word for brother. I was suddenly addressed in the same way as Mapuche address each other; I was thus included in their form of belonging. A similar transformation happened before my first trip to Wallmapu, when a Mapuche woman made the ironic remark that, if I get arrested in Wallmapu, they would start solidarity campaigns in Europe for me. Her statement is a beautiful expression of what belonging between Mapuche and non-Mapuche in that context could mean: receiving the same solidarity you were willing to give in the first place.

The feeling of belonging is one possible assemblage of the social relations of solidarity created by political solidarity. As a result of her activism, Amanda began to "feel connected with their cause and really involved in making the situation for them better [...]" (interview with the author, July 1, 2016). She feels this connectedness with the diasporic Mapuche organisation she supports, where everyone is "part of one group" and a "sense of community" is created. Her sense of belonging also includes the feeling of being "a part of a greater

21 For the notion of belonging, see Albiez et al. (2011). 
cause" as a result of having "grown to be a part of this" (Ibid.) through her commitment to the Mapuche diaspora.

More than that, Llanquiray Painemal argues that this feeling of belonging is a result of the commitment and the compromiso of non-Mapuche activists. She notes that, for example, Chileans who "have positioned themselves in support of the struggle of the Mapuche nation" are "counted as Mapuche" by the Mapuche themselves. In addition, "the Mapuche brother [...] is a Mapuche because he positioned him or herself [as such]" (interview with the author, June 16, 2017).

Along the lines of the abovementioned arguments, such a political positionality can hardly be nonperformative or just a declaration. Rather, such positionality needs to be put in practice as a sustainable mutual support that stems from a social relation and maintains a horizontal and reciprocal dynamic.

Assemblages of solidarity are in constant transformation, have a dynamic and processual character, and do not dictate a particular outcome. Assemblages of identification, recognition, and belonging are thus in constant movement and are creatively transformed by the actors involved. With this intense dynamic, encounters of solidarity thus create a mimetic excess because of the fact that the involved actors always relate to each other on the basis of what the other allows them to relate to. For example, whilst Llanquiray Painemal considers a non-Mapuche a Mapuche based on her/his political commitment, others could highlight another aspect that would justify that recognition. The idea of a mimetic excess (Taussig 1993) makes the representational relativity of the conditions for identifying, recognising, or belonging visible. A non-Mapuche can only identify with what he or she thinks of as a Mapuche society or culture but will never identify with it in an absolute or finite sense. And he or she will also only be able to identify with those aspects that others have shared with him or her based on their assumption of what he or she might be willing to accept, be interested in, and so on. Assemblages of solidarity thus include a dynamic process of constantly engaging and re-engaging with the other's mimesis.

Such a mimetic faculty is crucial for assembling new social bonds amongst the involved actors because it produces similarity, identification, or belonging. It is not relevant to determine or to prove whether a non-Mapuche activist actually embodies a Mapuche identity. Rather, it is about the question of whether a non-Mapuche has the mimetic faculty and is potentially able to reflect what a particular group or individual would consider a Mapuche char- 
acteristic. For example, Sybille says that she was tested on if she was able to fetch a loose sheep in the community she had visited. Besides her enjoyment of the task, she also realised that her host wanted "to check [...] if she is actually tough enough to spend some days in the mountains with us" (interview with the author, June 26,2016 ). Putting her toughness to the test could also include other dimensions, such as, for example, her reliability or willingness to get her hands dirty.

Testing the mimetic faculty of non-Mapuche mirrors the mimetic faculty of the Mapuche society and culture. ${ }^{22}$ In that way, the social excess of solidarity is not necessarily about belonging to and identifying with a particular set of cultural or social rules. Rather, it is about producing similar ways of relating to each other. It is not about establishing absolute sameness but about the question of whether sameness can be produced jointly through mutual exchange in which each party is willing to imitate the other. This resonates with the concept of mechanic solidarity, which demands a shared identification but, in the present case, is never a finished product.

The fact that "Mapuche communities have always been very integrating" (Llanquiray Painemal, interview with the author, June 16, 2017) also applies to encounters of solidarity. These encounters are possible and produce affinities as long as they mimic the mimetic faculty of the Mapuche. Since this faculty is a basic element for the social cohesion amongst the Mapuche society, relations of solidarity with non-Mapuche are essentially an extension of its sociality.

As extensions of the Mapuche society, assemblages of solidarity (re)create social bonds between Mapuche and non-Mapuche that are similar to kinship and friendship ties. One important element to understand the contemporary political mobilisation of the Mapuche society are its forms of social and political organisation (Morales Urra 2008; Stuchlik 1999). These forms are based "principally on structures of kinship, which determines the exogamy of a group and which politically meant the development of alliances between groups of relatives" (Gómez Leytón 2009; my translation).

Family associations and kinship ties play an important part in the present case by structuring and assembling relations of solidarity. Specifically, traumatic experiences within one's own family make kinship relations a reason to engage in solidarity action in the first place (Alex Mora, interview with the ferentiate and open themselves to outside elements, incorporating particular aspects in order to strengthen their own culture and society (Kaltmeier 2004, 42). 
author, November 28, 2015). Moreover, discourses of solidarity are influenced by family traditions (Llanquiray Painemal, interview with the author, June 16, 2017) and might lead to structures of political solidarity that resemble kinship relations (Alex Mora, interview with the author, November 28,2015 ).

The early experiences of the Mapuche diaspora in Europe in the 1980 s and '90s already resembled family and kinship relations. Today, many diasporic Mapuche organisations are the outcome of such family networks. At the same time, their solidarity efforts are organised and mediated through direct family ties and kinship relations with Wallmapu. For example, Andrea Cotrena explains that her "relations with Wallmapu are more oriented towards my family, who are struggling over there" (interview with the author, June 6, 2017). For her, solidarity actions essentially are "family support," "related to my land," and relevant because they "concern your own blood" (Ibid.).

Another noteworthy aspect is that international non-Mapuche solidarity activists rarely visit individuals, and are instead hosted within a Mapuche family network. Their encounters of solidarity are made possible by "very open and hospitable Mapuche families" and by the fact that they "partially live with Mapuche families," producing strong sentiments of belonging and closeness (Sybille, interview with the author, June 26, 2016). Such encounters assemble social relations of solidarity similar to kinship relations, in which the non-Mapuche guests are virtually treated as if they were kin (Luis and Nadia Painefil, interview with the author, March 10, 2016; Selma and Ramón Necul, interview with the author, March 11, 2016).

Such assemblages of solidarity as family relations have a concrete expression in the participation of non-Mapuche guests in Mapuche rituals or ceremonies like the nguillatun or the palin. ${ }^{23}$ During my first research stay in Wallmapu, I was invited to a palin between three Mapuche communities in order to celebrate the recuperation of one community's territory. I was invited as part of the family with whom I was staying for those days.

There are two possible ways to take part in a nguillatun as non-Mapuche guests. One is the experience of the team of JUPIC in Temuco, who have been invited to participate in nguillatun, never as a family unit, but as if they were part of a Mapuche family-in this case, the family of the community's longko. In the words of Fernando Díaz, they participated "as part of the family. As those who help" (interview with the author, March 26, 2016). In this case, the non-Mapuche (person or group) without their own piece of territory is invited 
as a guest of someone's family but has to return the favour and support that family's participation.

In the other case, and if the non-Mapuche group is considered to be part of a territoriality, a group can participate as metrem $^{24}$, a part of the alliance that is celebrated, performed, and reproduced during a nguillatun (Ibid.). This was the case of the JMM in Tirúa. Juan Fuenzálida says that their team has been invited to several nguillatun over the years but as part of their neighbouring Mapuche family, because "the nguillatun is a sort of a familial presence." However, on the last occasion, their team was invited as their own family unit and no longer as someone's guest. For him, "there is a validation in some way that we are a part of it, not just guests anymore, right? [...] You have an important gesture here, which says a lot" (Juan Fuenzálida, interview with the author, March 12, 2016). These very concrete experiences show that relations of political solidarity amongst non-Mapuche and Mapuche ultimately lead to social relations that resemble kinship relations, which might even lead to extending the whole sociality of Mapuche society.

Besides the assemblage of filiation and kinship, encounters of solidarity create bonds of friendship between non-Mapuche and Mapuche. Intimate and close relationships were described as opportunities to build friendships and trust amongst Mapuche and non-Mapuche (Amina, interview with the author, November 27, 2015; Peter, interview with the author, December 1, 2015). From a Mapuche perspective, non-Mapuche friends are called wenuy. Only very few non-Mapuche supporters, like Felipe Durán or Iban Gartzía, have been addressed publicly in that way. Some theoretical approaches to friendship highlight the emancipatory and decolonising potential of such relations and contrast them with relations of kinship and filiation as "possessive communities" (Gandhi 2006, 10). Nevertheless, the present context suggests something different and a solely negative connotation of kinship and filiation fails to recognise the possibilities of more horizontal and reciprocal assemblages amongst family and community networks. Conceptualising kinship as only hierarchical thus reproduces Eurocentric assumptions about vertical, patriarchal, and bourgeois family structures. Such assumptions are not necessarily the case for the Mapuche society. As bell hooks (2015b, 76-88) reminds us, (re)creating the (Black) family in the context of enslavement and structural racism can also be understood as a site of protection and resistance. 
The experiences of solidarity between Mapuche and non-Mapuche show that rather than establishing relations of friendships amongst individuals, non-Mapuche actors establish friendships with entire families. Also, already existing friendships enable to create more friendships, if, for example, person $\mathrm{X}$ introduces his friend $\mathrm{Y}$ to her other friend $\mathrm{Z}$. On that basis, the friendship between $\mathrm{Y}$ and $\mathrm{Z}$ can be forged.

Non-Mapuche actors describe their friendships with Mapuche as "getting along great" and "spending every day with them" (Amina, interview with the author, November 27, 2015). To become friends with Mapuche further means to be "able to talk about a lot of things with them, also about problems" and "to get a little bit of a different perspective on things" (Verena, interview with the author, December 6, 2015). Stories about friendships were also very present in conversations with Mapuche. In the diaspora in Europe, dispersed Mapuche "began to make friends and we started to unite us [the Mapuche in diaspora], to talk and to see how we could help our people in a real way" (Alex Mora, interview with the author, November 28,2015$)$. In that way, getting to know each other and starting to act in political solidarity is part of "building networks [and] friendships" (Llanquiray Painemal, interview with the author, June 16, 2017) and thus has an essentially social dimension. Solidarity is thus not a merely instrumental relation amongst people with the same political conviction, but one in which "you need to get closer towards friendship and trust" (José Luis Calfucura, interview with the author, February 16, 2016a).

For Rayen Kvyeh, for example, to "develop a feeling of strong friendship" means to "really love" the comrades who hosted her during her exile in Germany (interview with the author, March 1, 2016). Her trips to Europe in recent years do not only have a political or professional importance to her; these visits are not just a means to denounce the human rights violations in Wallmapu or to present her poetry. They rather have a social purpose in itself-the reproduction of friendships: "And, well, that moves me, and I am happy to go back and meet my friends, the comrades. Because the friendships that I have are also people, comrades, who work in solidarity because they believe in a better world, with more equilibrium" (Ibid.).

In her words, the friendships are the primary relations, and only afterwards are they highlighted as people who are engaged in solidarity action. In that way it seems that social solidarity produces political relations of solidarity. In such a perspective, international solidarity needs to be understood, in the first place, as assemblages of transnational and transcultural social rela- 
tions. Finally, it seems that the political action of transnational advocacy and international solidarity is only the next step.

A friendship thus becomes the point of departure to engage in a liberating and decolonising solidarity with the racialised, oppressed, and exploited Other (Dussel 2006). At the same time, such a friendship is also transformative for the relationship with one's own society. This is because such a friendship with the Other demands to transform former friends within the totality into enemies and former enemies outside the totality into friends. This radical and liberating notion of friendship demands to renounce one's privileges (one's friendships within the system) and become a traitor (an enemy) to the system through the quest for solidarity (becoming a friend to the Other). In contrast, if non-Mapuche actors do not transform their friends within the system into enemies, their solidarity does not only remain nonperformative but is complicit with an oppressive racialised social structure. Indeed, her inability to transform her host family into enemies is what excluded Clarissa from any possibility of a political, but foremost social, solidarity with the Mapuche.

The final empirical chapter presented and discussed critical practices and assemblages of solidarity across and beyond differences. The purpose of the critique was twofold: On the one hand, I developed a critique of solidarity practices that reproduce or reinforce colonial, racialised, and gendered hierarchies between Mapuche and non-Mapuche. On the other, I aimed at discovering critical practices that open the horizon to decolonise relations of solidarity across and beyond colonial differences and contribute to establishing truly ethical relations of solidarity. The chapter thus presented a critical notion of solidarity across and beyond differences based on three principles.

The first principle argued for solidarity as a form of compromiso-a longterm engagement and commitment that overcomes paternalistic practices and decentres white agency. Against such problematic practices, solidarity as compromiso requires cautiousness and a radical form of passivity by white supporters which respects the cultural politics of autonomy of the Mapuche. Critical practices of solidarity were sketched out through a series of metaphors that my interlocutors deployed. These metaphors conceived of critical practices of solidarity as a collective effort of 'building blocks,' as a process of healing, and as the experience of eating together from the same plate, expressed in the Mapuche notion of mizawvn. 
The second principle described solidarity as a (critical) practice of sharing, framed in the idea of compartir. This idea characterises solidarity as the exchange of material and immaterial goods, the sharing of spaces and gifts, as well as forms of spending/sharing time together. The chapter hereby looked at the different modalities of compartir and critically discussed whether these practices contribute to an exploitative or rather a reciprocal relationship between Mapuche and non-Mapuche actors.

The third principle delineated solidarity as a critical practice that (re)produces communal and social bonds between the involved actors, best expressed in the Mapuche ideas of keyuwvn and mingako-forms of mutual communal support. Critical practices and encounters of solidarity between Mapuche and non-Mapuche were depicted as mutually transformative, reciprocal, horizontal, intimate, and long lasting. I laid out how these factors transform the political encounters and relations of solidarity into social bonds amongst the involved actors. They hereby produce a series of assemblages through which the productive and transformative potential of a critical notion of solidarity becomes visible. Such assemblages, in the present case, were portrayed as processes of identification, recognition, belonging, mimesis, and, finally, as relations of kinship and friendship. 
